\title{
Fashioning Identities: convict dress in colonial South and Southeast Asia ${ }^{1}$
}

\author{
Clare Anderson \\ University of Leicester
}

As the British made inroads into the Indian subcontinent during the late eighteenth century, they were faced with a society which seemed both complex and elusive. They used various mechanisms in seeking to foster an understanding of socio-economic structures and hierarchies. The type of clothing that individuals, and groups of individuals, wore was one of these. Through dress, the British could divide the South Asian population into decipherable units and those units, in turn, could be distinguished from Europeans. Photographers involved in the compilation of ethnographic dictionaries during the late nineteenth and early twentieth centuries, for instance, dressed their subjects in what they believed to be 'typical' garments. These became visual signifiers of collective religious, caste or tribal (adivasi) status. ${ }^{2}$ Attempts to capture the essence of 'timeless' India, before the modernising colonial project transformed it beyond all recognition, meant that this even extended to clothing photographic subjects in garments long since abandoned. Edward Dalton's Descriptive Ethnology of Bengal (1872) included a photograph of two Juang girls dressed in leaves, which Dalton himself acknowledged they no longer wore. ${ }^{3}$

\footnotetext{
${ }^{1}$ As is inevitable with research of this type, much of the material referred to here was picked up inadvertently, during research trips to India, Mauritius and London. These visits were funded by the British Academy and the Carnegie Trust for the Universities of Scotland. I would like to thank them for their kind support. I presented an earlier version of this article at the Colonial Spaces, Convict Places: penal transportation in global context conference, University of Leicester, December 1999. I am grateful for the many useful comments made there. Additionally, I would like to thank the History Workshop Journal referees, Jane Caplan, Frank Conlon, Laura Gowing and Satadru Sen for their comments on earlier drafts.

${ }^{2}$ For an overview of ethnographic photography in India, see Christopher Pinney, 'Colonial Anthropology in the "Laboratory of Mankind", in C.A. Bayly, The Raj: India and the British (London, 1990), pp. 252-63; Pinney, 'Underneath the Banyan Tree: William Crooke and Photographic Depictions of Caste', in Elizabeth Edwards, ed., Anthropology and Photography, 1860-1920 (London, 1992), pp. 165-73; and, Christopher Pinney, Camera Indica: The Social Life of Indian Photographs (London, 1997).

${ }^{3}$ Pinney, Camera Indica, pp. 48-50.
} 
The desire to recognise also implied the need to control. Clothing, together with other bodily signs such as tattoos, ${ }^{4}$ hairstyles, moustaches and beards, were key to the identification of individuals for surveillance purposes. This was particularly true for those affected by the Criminal Tribes Acts. The first Criminal Tribes Act was passed in 1871, and at first extended across the North West Provinces, Awadh and the Panjab. By the mid-twentieth century, the Acts affected over thirteen million people. As Sanjay Nigam shows, the disciplinary measures taken û registration, surveillance and resettlement - sought to reclaim individuals as 'moral subjects of the Raj'. ${ }^{5}$ In a bid to identify those transgressing the terms of the Acts, police handbooks detailed the types of clothing typically worn by the criminal tribes. The oudhias for instance were said to wear a white linen cap, a white jacket and a short dhoti, and to carry an umbrella and a stick. Such information, they believed, would facilitate arrest. ${ }^{6}$ Increasingly, clothing was also a means through which racialized social boundaries were established. In his work on colonial knowledge formation, Bernard S. Cohn has emphasized how cultural distancing - 'social separation' - between Indians and Europeans in South Asia was facilitated through differing dress. ${ }^{7}$ Indian men commonly wore either a basic loin cloth (langoti) or a longer waist cloth (dhoti). Their upper body was either left uncovered or, in cooler weather, wrapped with a chadar (shawl). In some regions, a pagri (turban) completed the outfit. During the

\footnotetext{
${ }^{4}$ On the use of decorative tattooing for surveillance purposes, see my own, 'Godna: inscribing Indian convicts in the nineteenth century', in Jane Caplan, ed., Writing on the Body: the tattoo in European and North American History (London, 2000), pp. 105-6.

${ }^{5}$ On the Criminal Tribes, see: Crispin Bates, 'Race, Caste and Tribe in Central India: The Early Origins of Indian Anthropometry', in P. Robb (ed.), The Concept of Race in South Asia (New Delhi, 1995), pp. 219-257; Sanjay Nigam, 'Disciplining and Policing The "Criminals By Birth", Part 1: The making of a colonial stereotype - The criminal tribes and castes of North India, Indian Economic and Social History Review, 27, 2 (1990), pp. 131-64 and 'Disciplining and Policing The "Criminals By Birth”, Part 2: The development of a disciplinary system, 1871-1900', Indian Economic and Social History Review, 27, 3 (1990), pp. 257-87 (quote, p. 287); and Anand A. Yang, 'Dangerous Castes and Tribes: the Criminal Tribes Act and the Magahiya Doms of Northeast India', in Crime and Criminality in British India, ed. Anand A. Yang, (Tuscon, 1985), pp. 108-27.

${ }^{6}$ See, for example: E.J. Gunthorpe, Notes on Criminal Tribes Residing in or Frequenting the Bombay Presidency, Berar and the Central Provinces (Bombay, 1882), p. 66; S.T. Hollins, The Criminal Tribes of the United Provinces (Allahabad, 1914), p. 83; and, IOR F161/157 (Inspector-General's Standing Order No.62: note on the criminal tribes in the Punjab 1944).

${ }^{7}$ Bernard S. Cohn, Colonialism and Its Forms of Knowledge: The British in India (Oxford, 1997), pp. 111.
} 
Sultanate and Moghul periods, stitched clothing such as long-sleeved outer robes (jama), tunics (kurta) and trousers (pyjamas) became more common. As the contemporary anthropologist Emma Tarlo shows, women either wore saris, long pieces of plain or decorated cloth wrapped around the lower body with one end draped over the torso, or long tunics (kamiz) and trousers (shalwar), with a veil (dupatta). Towards the end of the nineteenth century, blouses were also worn under the $s a r i .{ }^{8}$ All were a stark contrast to European dress, which was heavily tailored and often restrictive. ${ }^{9}$

Both Indian and European dress, of course, varied considerably, largely on the basis of class, status and gender. Yet as the East India Company consolidated its interests in the subcontinent, and moved to end the social integration more common to eighteenth-century contact, clothing was increasingly viewed as a marker of the desired racial separation between 'European' and 'Indian'. ${ }^{10}$ The 1857 Uprising was a major catalyst to this. While locally raised East India Company troops were initially dressed in 'native fashion' and military coats, they had gradually become more European in appearance, wearing tight coatees with long tails. However, after 1857, when the army was reorganised, it became far more Indian in appearance. Sepoys (soldiers) were permitted to wear turbans and clothing became looser in style. ${ }^{11}$ Already in 1830, the Company had banned civilian Europeans from wearing Indian dress at public functions. By the end of the century, Europeans ridiculed those Indians who sought to emulate their clothing. ${ }^{12}$

Despite this, throughout the nineteenth century it was common practice for Indians to wear European dress. In areas of European settlement Indians wore cast-off

\footnotetext{
${ }^{8}$ Emma Tarlo, Clothing Matters: Dress and Identity in India (London, 1996), p. 28. Tarlo contends that Cohn's assertion that stitched clothing entered India with the Moghuls is incorrect.

${ }^{9}$ Cohn, Colonialism, p. 130.

${ }^{10}$ See also Christopher Breward, on how descriptive accounts of clothing were instrumental in negotiating a sense of national identity and membership of the 'imperial race' in the metropole: 'Sartorial spectacle: clothing and masculine identities in the imperial city, 1860-1914', in Felix Driver and David Gilbert, eds, Imperial Cities (Manchester, 1999), pp. 238-53.

11 Thomas S. Abler, Hinterland Warriors and Military Dress: European Empires and Exotic Uniforms (Oxford, 1999), pp. 112-20.

12 Tarlo, Clothing Matters, pp. 36-42.
} 
official uniforms. In 1852, two indentured labourers returning from Mauritius were found in possession of a Royal Artillery soldier's coat, several other articles of soldiers' apparel and a police badge. ${ }^{13}$ By the 1890 s, workers on the coffee estates in the northeast were said to don soldiers' jackets, unsurprising given the cool climate in the hills. ${ }^{14}$ In addition, entertainers, musicians and bandsmen in Calcutta all wore old police and army hats, jackets, coats, buttons and pantaloons. There were frequent auctions of such goods. ${ }^{15}$ In Calcutta, there was even a shop where uniforms could be hired. W.H.H. Vincent, an official in the Twenty-Four Parganas district, reported in 1896 of the 'foofoo bandsmen' who paraded in Calcutta, 'dressed up like slovenly soldiers'. This, he said, was a direct challenge to British prestige. ${ }^{16}$ J.A. Bourdillon, the Commissioner of Burdwan, also wrote of the 'disreputable raggamuffins' who worked as musicians in Calcutta. He too was worried about the threat they posed to British 'dignity'. Of greater concern to him were the increasingly common theatrical representations of Europeans. Actors were apparently dressed up in European clothing and 'made the butt of the piece, and treated with every kind of indignity amidst the uproarious applause of the audience.' 17

When Indians wore European garb, the boundaries between colonizer and colonized began to break down. Edgar Thurston, Superintendent of Ethnography, Madras, wrote with contempt in 1906 of the "change for the worst [sic] in native male attire'. The examples of declining standards that he cited included Indians wearing brightly coloured caps instead of turbans, Bengali clerks donning patent leather boots and Indian cricketers' bright blazers, reminiscent of those worn by English public

\footnotetext{
${ }^{13}$ India Office Records (IOR) P/144/20 (8 April 1852). E.A. Samuells, Magistrate of the Twenty-Four Parganas, to J.P. Grant, Secretary to Government, 9 March 1852.

${ }^{14}$ National Archives of India (NAI) Home (Public), A proceedings, July 1896, nos 139-67. R.C.C. Carr, Acting Secretary, Revenue Department, 5 December 1895.

15 At auction, unlined military coats sold for between 12 and 14 annas; if they were lined, as much as 1-4-0 rupees. English police coats fetched even more: 1-6-0 rupees. NAI Home (Public), A proceedings, July 1896, nos 139-67. Note by W.E. Young, Collector of Customs Karachi, 18 February 1896.

${ }^{16}$ NAI Home (Public), A proceedings, July 1896, nos 139-67. W.H.H. Vincent, Officiating Magistrate, Twenty-Four Parganas, 14 November 1895.

${ }^{17}$ NAI Home (Public), A proceedings, July 1896, nos 139-67. J.A. Bourdillon, Commissioner of Burdwan, 22 January 1896.
} 
school teams. ${ }^{18}$ It was this foray into wearing the outfit of the Englishman which was the cause of most concern.

Thus we begin to see, as Margaret Maynard argues in a fine study of dress in colonial Australia, that clothing is not simply utilitarian, but 'functions on many levels and serves a number of purposes.' These functions include the establishment and negotiation of power relationships. ${ }^{19}$ To at least some extent, individuals choose their self-image and interpret their identity through clothing. Yet clothing can also be a means through which individuals have their identities fashioned for them. ${ }^{20}$ When individuals use dress to cross those boundaries, profound anxieties arise.

This article explores the issue of clothing in India's penal settlements. From the late eighteenth to the mid twentieth centuries, the British transported tens of thousands of Indian convicts overseas to penal settlements in Southeast Asia, Mauritius and the Andaman Islands. Removed from their supposedly criminal networks and put to work, convict offenders were apparently rehabilitated whilst conveniently satisfying colonial labour demands. The organisation of the penal settlements relied on a division of convicts. According to skills, behaviour and proportion of sentence served, convicts could rise through the ranks of the penal hierarchy and be transferred from hard labour to preferred work tasks or positions of authority over their fellow countrymen and women.

The most immediately visible marker of convict status was dress. By the midnineteenth century, a complex system of uniform clothing had evolved, delineating how long convicts had been in the penal settlements and how they were employed there; later, clothing was further adapted to indicate categories of crime. Initially, the evolution of convict dress was informed by developments in the Australian penal

\footnotetext{
18 E. Thurston, Ethnographic Notes in Southern India (Madras, 1906), p. 520. .

${ }_{19}$ Margaret Maynard, Fashioned From Penury: Dress as Cultural Practice in Colonial Australia (Cambridge, 1998), p. 2. Karen Sayer similarly argues that in Victorian Britain dress marked racial, class and gender identities: “"A sufficiency of clothing": dress and domesticity in Victorian Britain', unpublished paper presented at The Dress of the Poor, 1750-1900 conference, Oxford Brookes University, 27 November 1999.

20 Tarlo, Clothing Matters, pp. 8 and 318.
} 
settlements. Later, and more significantly, initiatives on prison dress in India became important. However, as we will see, the development of penal clothing in the Indian convict settlements overseas also had an agenda of its own.

As Margaret Maynard shows, penal dress was integral to the management of convicts in Australia. The overwhelming majority of convicts were from the British Isles, as were most free emigrants. Clothing was thus a means through which the social hierarchy, between an overwhelmingly white community, could be ordered. From the 1790s, soon after the arrival of the First Fleet at Botany Bay, attempts were made to develop convict uniforms. Problems with colonial supplies meant these were effectively standard working class dress. This often led to problems in distinguishing convicts from free settlers. By the 1820 s, convicts were more uniformly dressed, with convicts issued with clothes that were numbered and marked with broad arrows. ${ }^{21}$ Hierarchies between convicts were also outlined through clothing. Male convict overseers wore special dress whilst convict women were divided into classes, each wearing different clothes. ${ }^{22}$

Given these developments in the main late eighteenth- and nineteenth-century destinations for forced convict migrants from the British Isles, it is perhaps unremarkable that the principle of standardized dress was also extended to the Indian convict diaspora. However, various contexts, differing imperatives and the long duration of the penal settlements in Southeast Asia and the Indian Ocean - almost 150 years - resulted in a series of changes in its nature, function and significance.

Unlike Australia where there were attempts to standardize dress shortly after the first convicts arrived, during the early years of transportation from South Asia in the late eighteenth century, no uniforms per se were issued. From the late eighteenth and early nineteenth centuries, male convicts were given standard 'Indian' clothing: a piece of white cloth, to be worn as a dhoti, on departure from the transportation jails,

\footnotetext{
${ }^{21}$ Maynard, Fashioned From Penury, chapter 1.

22 Ibid., p. 14 and 24.
} 
Alipore (Calcutta), Tannah (Bombay) and Chingleput (Madras). Replacement supplies were subsequently issued twice a year. For the whole duration of the Mauritian settlement (1815-53), for instance, Patna chintz was imported for the use of convicts there. Six yards of white cloth and a cumlie (blanket) were issued twice a year. ${ }^{23}$ The East India Company provided a similar amount of clothing for convicts in its Southeast Asian penal settlements at Arakan, Bencoolen, Tenasserim, Singapore, Malacca and Penang. We know very little of the clothing worn by female convicts. So few were transported - just six were shipped to Mauritius, for instance - that only sparse records survive.

Until at least the 1840 s, there were no sanctions preventing convicts from wearing other clothes. Although they were transported in standard issue, many convicts took supplementary clothing with them from India. The Superintendent of Police, Bombay, wrote of the immense quantity of baggage one group of convicts transported in 1839 had with them on embarkation. ${ }^{24}$ In 1846, another contingent of convicts' luggage capsized the boat on which they were being taken to their transportation ship. One convict fell overboard and drowned. ${ }^{25}$ Clothing was taken for one of two purposes: either personal use or as a potential means of exchange in contraband trading. ${ }^{26}$ As convicts often worked in cool temperatures or in places affected by seasonal monsoons, additional clothing was very desirable. The need for warmer clothing than the standard dhoti was only recognized in 1839 , when, on the recommendation of the Medical Board, and in response to concerns about high mortality rates, each convict was, in addition to standard cloth, issued with a coarse woollen pair of trousers and jacket upon embarkation. ${ }^{27}$

\footnotetext{
23 See indents on the Commissariat: Mauritius Archives (MA) RA54 (September 1817) and MA RA1067 (January 1850).

24 IOR P/402/32 (17 April 1839). J.M. Short, Superintendent of Police Bombay, to J.P. Willoughby, Secretary to Government Bombay, 3 April 1839.

25 IOR P/142/52 (19 August 1846). R.H. Mytton to F.J. Halliday, 10 August 1846.

26 In Australia too, convicts commonly used clothing as a means of exchange. See the Bigge Reports (Parliamentary Papers), State of the Colony of New South Wales, 1822, vol. 20, pp. 60-1 ff.

27 IOR P/402/37 (18 September 1839). J. Glen, Secretary to the Medical Board, to L.R. Reid, Acting Chief Secretary to Government Bombay, 12 August 1839.
} 
The reasons for the seeming lack of concern over convict dress at this time are threefold. First, until 1849, most transportation convicts from the Bengal and Madras Presidencies, including women, were tattooed on the forehead with penal godna markings, detailing their name, crime and date of sentence. This was both punishment and stigma, an indelible means of social differentiation. Convicts were thus readily distinguished as convicts, no matter what they wore. ${ }^{28}$ Second, in most of the penal settlements, and despite their wide-ranging regional origin, they formed a discreet ethnic group. In Mauritius, for instance, before the onset of indentured immigration in the 1830 s, there was only a relatively small Indian diaspora on the island. Indian convicts were thus easily recognizable, visually far removed from the white, creole (Mauritian-born), slave and, later, apprentice populations. ${ }^{29}$ The same was true for Bencoolen and the Straits Settlements (Malacca, Penang and Singapore). Indeed, white settlers' arguments against the transportation of Hong Kong convicts to the Straits in the mid-nineteenth century focused on the ease with which they would be able to escape by blending in with the free population, in contrast to those convicts already there. Third, the colonial treasury made considerable financial savings by allowing convicts to wear their own clothes. Given each settlement's responsibility for providing the cost of convict subsistence, this kept the cost of convict labour down. Of course, if convicts wore different clothing, the colonial authorities were also able to differentiate between them. If the need for identification arose, as it sometimes did when convicts were brought to trial for offences committed after transportation, or committed suicide, this could be to their benefit.

Convicts often possessed a substantial number of garments. During the annual Moharrum (Yamsé) celebrations in Mauritius, for instance, convicts dressed to impress. They apparently wore white and red turbans, plain and checked waistcoats,

\footnotetext{
28 Anderson, 'Godna: inscribing Indian convicts', pp. 102-17.

29 The first Mauritian census (1826) recorded a composite category of 14000 Indians, Chinese and creoles, 9000 whites and 63000 slaves. Given the island's history as a slave colony, one must assume that creoles formed the largest proportion of the composite category. Public Record Office (PRO) CO172.42. Baron d'Unienville, Tableaux de Statistiques, tableau no. 6.
} 
brightly coloured jackets, knee-length trousers and leather belts. ${ }^{30}$ Yet even during normal working hours, convicts on the island donned non-standard issue. Cotton trousers and shirts, waistcoats and jackets were all commonly worn by convicts, in place of or in addition to their dhotis. ${ }^{31}$ There is some evidence, for example, that Muslim convicts in Mauritius wore different clothing to Hindus, though this may also have related to convicts' region of origin. ${ }^{32}$ Whilst convicts brought some of their clothes to the island, it is likely that many other items were soldiers' cast-offs, acquired through the complex networks of contraband trade already well established in Mauritius before convicts arrived. Indeed, convicts were commonly referred to as sepoys, which reflected the mistaken belief that they were soldiers imprisoned as British political prisoners. ${ }^{33}$ No doubt this image was compounded and perhaps even encouraged by convicts themselves, through wearing old army uniforms. When one of the Indian convicts transferred from Mauritius to Madagascar in the 1820s, as part of Britain's policy of establishing friendly relations in the Indian Ocean, died, his personal effects included a soldier's jacket, two black jackets, a turban and a piece of white cloth. ${ }^{34}$

Despite efforts to contain it, the trafficking of stolen cloth was common throughout the penal settlements. An early proclamation issued in Bencoolen

\footnotetext{
${ }^{30}$ MA JB332. Trial of Massooben Ramjee, Luckoo Puddhoo, Arribapou and Ragoo. Evidence of the Court of First Instance, 4 May 1843. These four Bombay convicts were acquitted of murdering a nonconvict Indian, Soulal, in an alleged dispute over an Indian woman named Singui. Other criminal trials involving convicts also detail the clothing they wore - evidence for the identification of individuals. ${ }^{31}$ Another good source on convict clothing in Mauritius can be found in the MA JI (post-mortems) series. A description of the clothing of two convict suicides is, for example, recorded at MA JI11, Bhelo Kalipa, July 1831 and JI12, Renbella, April 1831. Mrs Bartrum, who lived in the colony between 1820-7, also noted that convicts wore white and red turbans. See Recollections of Seven Years Residence at the Mauritius, or Isle of France; By a Lady (London, 1830), pp. 123-4.

${ }^{32}$ MA Z2A36. Descriptions of three Bombay convicts who marooned from the Depot of Grand River, 25 March 1827. The convicts were named as Heringa Vulud Donepa, Hooloorah Bedur and Shree Newas Achary. The Head Convict Overseer, W. Staveley, noted: 'The men are dressed something like the Musslemen, with a white short gown, and thin cloth thrown over their shoulders and at times cover themselves with their cumlies.' Note once more that clothing was a potential means of identification, especially significant for convicts from Bombay, as they were not marked with godna on the forehead. 33 On the crimes for which convicts were convicted, see my own Convicts in the Indian Ocean: Transportation From South Asia to Mauritius, 1815-53 (London, 2000), Appendices B1 and B2. ${ }^{34}$ MA RA387/415. R. Lyall, Political Agent Madagascar, to G.A. Barry, Colonial Secretary Mauritius, 26 December 1828 and 1 September 1829, enclosing a 'Memorandum respecting the Sepoys [convicts] in Madagascar'.
} 
prohibited all persons buying cloth (or other goods) from convicts. Nevertheless, a healthy traffic existed. In 1806, two convicts were executed for their part in the theft of cloth worth a massive $\$ 1200 .{ }^{35}$ After 1845 , in an indication of the epic proportions that contraband trading had reached, convicts in Singapore, Penang and Malacca were forbidden from selling or bartering their clothes or blankets. ${ }^{36}$ Stolen goods recovered in the Mauritian convict camps in the period 1819-40 included: a roll of twill cloth, a roll of silk, a roll of white cotton, a roll of blue cloth, a white shirt, a flannel shirt, a pair of Nankin trousers, a linen jacket, a silk jacket, a linen handkerchief, a large white handkerchief with a red flowered pattern, two Chinese crêpe shawls, two 'Indian caps', a Patna shawl, a Patna shirt, a waistcoat and 42 pairs of slippers. ${ }^{37}$ Cloth and clothing gave convicts social clout, both with their convict camarades and the wider Mauritian community. This both facilitated their participation in economic exchange and, in these grossly gender-imbalanced penal communities, also gave them the potential to attract female partners, convict or otherwise.

The first attempts to standardize Indian convict dress came in the Southeast Asian penal settlements, from the late 1830s. This was some 20 years earlier than initiatives in mainland Indian jails. In 1839 the Bombay authorities ordered that convicts were to be transported with only a limited amount of clothing, to stop them making money by trading their clothes. ${ }^{38}$ After 1850 , when convicts in the Straits Settlements were reorganised, they were given new types of standard dress. The issue depended on each convict's place in the new class system, instigated by W.J. Butterworth, Governor of the Straits, in his 1845 Code of Rules. Convicts in the Straits Settlements were divided into five classes. The fifth class was composed of those convicted of serious crimes, and those convicted of secondary offences in the settlement. The fourth class was composed of term convicts and those convicted of

\footnotetext{
35 IOR P/129/32 (1 January 1808). Extract from a letter from the Resident at Bencoolen, 15 August 1806. $\$=$ Spanish dollar, or piastre, worth approximately $45 \mathrm{~d}$.

36 IOR P/142/37 (17 September 1845). W.J. Butterworth, Governor of Prince of Wales' Island, Singapore and Malacca, to A. Turnbull, Under Secretary to Government Bengal, 26 February 1845.

${ }^{37}$ Anderson, Convicts in the Indian Ocean, chapter 5.

${ }^{38}$ IOR P/402/32 (17 April 1839). J. Farish, Governor of Bombay, to J.M. Short, 3 April 1839.
} 
less serious offences. The third class contained those promoted from the fourth class. Peons and those working for the Convict Department as overseers, or tindals, were placed in the second class. First class convicts had already served 16 years of their life sentence (term convicts were never transported for more than 14 years) and were allowed to live out of the convict settlement. Each class had varying privileges, relating to rations and money gratuities. Promotion and demotion between classes provided both positive and negative incentives for good behaviour. ${ }^{39}$

In the early years of the penal settlements, convict overseers were simply issued with a 'belt'. ${ }^{40}$ The first attempt to clothe first class convicts - who were frequently employed as tindals - differently came in 1850 when W.J. Butterworth provided them with special uniforms. Some convicts initially refused to wear them. We can only speculate why. Butterworth put their reaction down to caste prejudices, a typical colonial reading of convict resistance to change in the penal settlements at this time. ${ }^{41}$ Convict tindals themselves may have been more concerned about losing the autonomy to dress as they pleased, or at being so obviously differentiated from ordinary convicts. In relation to the second point, it was later claimed that Andamanese tribals targeted convict overseers in the Andaman Islands during their attacks on working parties. Convict overseers thus often removed the visible symbols of authority - turbans, badges and belts - and carried tools when going out with to work. ${ }^{42}$ Whatever the case - and convict voices are typically absent from the account the objections of convicts tindals were eventually overcome. Together with peons, orderlies and munshis (timekeepers), they were issued with various belts and brass plates. Additionally, first class Indian convicts otherwise employed were permitted to wear clothes of their choice. A demonstration of a lengthy period of good behaviour, this enabled them to find work with private employers which was a step in their

\footnotetext{
${ }^{39}$ IOR P/142/37 (17 September 1845). W.J. Butterworth to A. Turnbull, 26 February 1845.

40 IOR P/142/37 (17 September 1845). Present system of management and discipline of convicts at Singapore, Superintendent D.A. Stevenson, 9 January 1845.

${ }^{41}$ IOR P/143/56 (9 October 1850). W.J. Butterworth to J.W. Dalrymple, 14 May 1850.

42 M.V. Portman, A History of Our Relations With the Andamanese: compiled from histories and travels, and from the records of the Government of India, Volume I (Calcutta, 1899), pp. 277-8.
} 
rehabilitation, integration into the free population and subsequent removal from the coffers of the convict system. Clothing was also used to express socio-racial divisions in the penal settlements. The handful of European convict warders - themselves ticket-of-leave European prisoners convicted in India and shipped to the Straits Settlements û were issued with a light blue loose coat and a cap bordered with lace. A distinctive badge, such as a hammer and chisel crossed for artificers, was given to indicate their grade. ${ }^{43}$ Twice a year, the second, third, fourth and fifth classes were given nine yards of grey shirting, one jail suit, two working suits and a cap. The outfits - and use of fetters - differed slightly according to penal class. It seems likely that women were given cloth to wear as a sari. This was certainly the case later on in the Andaman Islands, as we will see.

The initial difficulties Butterworth faced in issuing convicts with hierarchising dress raise a number of issues relating to the relationship between clothing and the negotiation of power relations. One obvious implication of the standardization of dress was to ignore the possible significance of religion and/or caste to individuals. ${ }^{44}$ As David Arnold shows, in mainland Indian jails, religion and caste did impact upon prison discipline. ${ }^{45}$ Jail administrators wanted to standardize punishment, but they also wished to avoid accusations that they were interfering in questions of caste, which could and did lead to episodes of prison unrest. ${ }^{46}$ These imperatives were essentially incompatible; officials acknowledged that the close social contact integral to incarceration had a different impact depending on caste. In 1823, for example, the Commissioner of the Deccan, in response to Brahmin prisoners' complaints about the

\footnotetext{
43 J.F.A. McNair, Prisoners Their Own Warders: A Record of the Convict Prison at Singapore in the Straits Settlements established 1825, Discontinued 1873, together with a Cursory History of the Convict Establishments at Bencoolen, Penang and Malacca from the Year 1797 (London, 1899), pp. 94-5.

${ }^{44}$ On British perceptions of caste in India see: Lucy Carroll, 'Colonial Perceptions of Indian Society and the Emergence of Caste(s) Associations', Journal of Asian Studies, 37, 2 (February 1978), pp. 23351; Ronald Inden, 'Orientalist Constructions of India', Modern Asian Studies, 20, 3 (1986), pp. 401-46; Ronald Inden, Imagining India (Oxford, 1990).

${ }^{45}$ For a discussion of caste in Indian jails, see David Arnold, 'The Colonial Prison: Power, Knowledge and Penology in Nineteenth-Century India', in Subaltern Studies VIII; Essays in Honour of Ranajit Guha, eds David Arnold \& David Hardiman, (New Delhi, 1994), pp. 170-5.

${ }^{46}$ Arnold, 'The Colonial Prison', pp. 151-3.
} 
lack of caste differentiation in the Ahmednuggur Jail wards, wrote: 'If [Brahmins] are not separated at all from the inferior castes their punishment by this admixture may be deemed to be greater than was contemplated, since degradation or perhaps pollution is added [to] the penalty of imprisonment.' 47 The Secretary to Government Bombay added that mixing castes within the jails 'may even be so repugnant to native manners that it should not be admitted into a sentence.' 48

As the number of petitions referred to government from the 1820 s reveals, defence of caste or religion was an issue for large numbers of prisoners. In some jails prisoners' concerns were taken more seriously than in others, and were integral to prison management. Until the mid-1820s, the division of individuals according to caste was integral to some regimes. Others ignored prisoner preferences and segregated inmates according to their crime or sentence. ${ }^{49}$ In Alipore Jail in Calcutta, which had no system of classification at all, jail administrators commonly expressed the sentiment that mixing castes prevented mass escapes. ${ }^{50}$ During the first half of the nineteenth century, the Bombay Presidency was by far the most willing to accommodate caste in jail. In 1824, the administration directed that Brahmins for whom imprisonment risked loss of caste should, where possible, be accommodated separately. At the very least, they should not be placed in the same cells as Muslims or low-caste Hindus and allowed to prepare their food separately. ${ }^{51}$ The 1838 Committee of Prison Discipline, whilst acknowledging the diversity of jail classification throughout India, later criticized Bombay in this respect. ${ }^{52}$ Officially at least, 'caste prejudices' were not to affect prison discipline. In practice, from the 1840 s they were viewed as too important to ignore. 53

\footnotetext{
47 IOR P/399/33 (12 May 1824). W. Chaplin, Commissioner of Deccan, to H. Pottinger, Collector Khandesh, 25 December 1823.

48 Ibid. J. Farish to W. Chaplin, 6 May 1824.

49 Ibid.

${ }^{50}$ IOR P/399/36 (4 August 1824). J.E. Grant, Register to Sudder Adalat [Supreme Court] Bombay, to J. Farish, 17 July 1824.

51 Ibid. J. Farish to J.E. Grant, 29 July 1824.

52 Report of the Committee on Prison Discipline (Calcutta, 1838), pp. 24 and 66.

53 Arnold, 'The Colonial Prison', pp. 170-1.
} 
What of the privileging of caste amongst transported convicts? Broadly speaking, the Mauritian and Southeast Asian penal settlements followed the Indian pattern. Initially, there was great diversity between them. In Mauritius, convicts were not messed together according to caste, but were given rations with which to prepare their own food. Additionally, officials sometimes took crude Brahminical interpretations of the caste hierarchy into consideration when allocating convicts to particular occupational tasks. Attendants on the Civil Hospital's convict wards, for instance, were recruited from 'low-caste' men. ${ }^{54}$ Brahmins read out Convict Department notices in the convict camps. ${ }^{55}$ In the Tenasserim Provinces (Burma), at least as late as 1838 , convicts were messed together according to caste. ${ }^{56}$ Generally speaking, however, it was more common for convicts in the early settlements to prepare their own rations. Indeed, when in 1835 a convict in Mauritius sentenced to 20 years' hard labour for a secondary offence refused to eat his ready-prepared food, he was given permission to prepare it himself in future. ${ }^{57}$ This was not the case during the later period of the penal settlement in Singapore. Here, the mixing of convicts was a deliberate policy and, as in certain Indian prisons, was seen as a safeguard against revolts. W.J. Butterworth and J.F.A. McNair both echoed earlier opinions in India, writing that mixing castes prevented threatening combinations. ${ }^{58}$

With the drive towards uniformity in mainland Indian jails, questions of caste became inextricably linked to questions of dress. In 1855, a prison circular directed that Bengal prisoners should only be in possession of the jail allowance of clothing. ${ }^{59}$ In Chittagong jail, Muslim prisoners were subsequently ordered to remove their caps. This caused uproar, not least from the prisoners themselves. The Inspector-General of

\footnotetext{
54 MA RA601. Letter from A. Montgomery, Surgeon-in-Charge of the Civil Hospital, to Charles St. John, Chief Medical Officer, 21 October 1840.

55 MA RA915. Report of the Committee on Convicts: Memorandum, 30 August 1847.

${ }^{56}$ Committee on Prison Discipline, p. 263.

${ }^{57}$ MA Z2A79. E.A. Williams, Acting Procureur Général, to J. Finniss, Chief of Police, 21 March 1835 .

${ }^{58}$ IOR P/142/37 (17 September 1845). W.J. Butterworth to A. Turnbull, 26 February 1845 and McNair, Prisoners Their Own Warders, pp. 53-4 \& 123.

59 IOR P/145/31 (24 January 1856). F.J. Mouat, Inspector-General of Prisons Lower Provinces, to A.W. Russell, Under Secretary to Government Bengal, 26 December 1855.
} 
Prisons, Bengal, F.J. Mouat, later condemned the Magistrate of the District, writing: 'The skull cap is an essential part of the dress of a Mahomedan; and to be without it is, in their estimation, to be unsuitably clothed ... No good in jail discipline and punishment can be effected by interference in such matters. ${ }^{60}$ Other communities were given similar concessions on dress. In keeping with its more accommodating attitude to prisoners' socio-religious status, in the Bombay Presidency Parsi prisoners were allowed to wear sadras (long undergarments) and Brahmins sowla cloths, when eating. Both were also allowed to wear a janwa and kasti. ${ }^{61}$ Christians, otherwise indistinguishable from their convict compatriots, were clothed differently throughout the penal settlements. In the Tenasserim Provinces, for instance, they were given a kilt in lieu of a dhoti. ${ }^{62}$

From the late 1830s, as more standardized prison uniforms were developed in the penal settlements overseas, conflicts on the question of caste/religion and dress inevitably occurred there too. Concessions on dress were, on occasion, granted to transportation convicts. As we have seen, upon embarkation, transportees were issued with standard convict dress. Yet, at least in theory, they were allowed to keep clothing connected with religious duties or customs. In one instance, three Parsi convicts petitioned the Bombay Government in 1839 after a police constable forcibly removed their sadras before their embarkation to Penang and Singapore. The man responsible, William Read, was called upon to explain his actions. He described how he had boarded the ship Adelaide to check the convicts were properly secured, had no dangerous weapons and had sufficient rations for the journey, continuing:

\footnotetext{
The [Parsis] were dressed in their usual dress. I called them below for the purpose of being inspected and when they came I asked them to point out their berth and supply of clothing. They said they did not
}

\footnotetext{
60 Ibid.

61 Arnold, 'The Colonial Prison', p. 174.

62 IOR P/143/6 (1 September 1847). Memo of Half-Yearly Clothing Issue, Major H. Bower, Magistrate Mergui Jail, 22 July 1847.
} 
know where their clothing was; seeing 3 spare mats and cloth on [their berth] I pointed it out as theirs. They said they did not want any. I desired them to take off their clothes and put on the convicts [sic] dress - they said 'no' they did not do it on Board the last vessel and would not do it in this. I took off the Turban of one and commenced untying his angreka when they began to undress themselves and were very abusive - I then observed that they had their convict trowsers on under the others - I told them to take off their Suddra [sadra] which they refused to do, on which I began to do it myself - one of them made a blow at me, when I called one of the Police man [sic] to come to my assistance, and see that they took of the Suddra, when they took them off themselves - as I was leaving, one of them came to me and very violently held up his 'Kustee' which he told me I had better take also but knowing this to be connected with their Religeon [sic] I refused. ${ }^{63}$

Read claimed that he had not been aware of the religious significance of the Parsis' clothes. The Sheriff of Bombay promised that there would be no future interference with convicts' 'religious prejudices'. ${ }^{64}$

There was of course considerable space for convicts to manipulate colonial perceptions about religion or caste to their own advantage. In seeking concessions on dress, the problem for convicts was to convince officials that their clothing had a specifically religious, as opposed to social status, connotation. Not all were as successful as the Parsis discussed above. Shreerustna Wassoodewjee, a Bombay convict transported to Singapore in 1846, petitioned:

63 IOR P/402/32 (1 May 1839). Statement of W. Read, Head Constable Fort Division, Bombay Police, 26 April 1839.

${ }^{64}$ Ibid. J.L. Johnson, Sheriff of Bombay, to J.P. Willoughby, 17 May 1839. 
he is a member of a high class of Hindu and not capable of wearing a cap and trousers and therefore humbly trusts that your generous feelings will prompt you to grant him as a special favor the prevelege [sic] of being dressed in a manner suitable to his caste. ${ }^{65}$

By this time, a more standardized uniform was in place in the settlement. The authorities were still willing to grant concessions to high caste communities, but Wassoodewjee only claimed he was a 'high class of Hindu' and the convict authorities countered that he was not a Brahmin and thus no better entitled to sympathetic treatment than many other convicts. ${ }^{66}$

Prison uniform in the Indian subcontinent was first introduced in the 1860s, some years after it had been introduced for convicts transported to the Straits Settlements. At first, uniforms were not standardized and varied to some degree between districts. In 1860, F.J. Mouat, Inspector-General of Prisons in Bengal, recommended the use of 'special prison dress', a check-patterned jacket and dhoti which he claimed would not affect caste, ${ }^{67}$ on what grounds are unclear. After the 1864 Jail Committee, which recommended the division of prisoners into classes according to their offence and 'character', dress was used as a distinguishing tool. Thus in the North-West Provinces, Awadh, the Central Provinces, Mysore and Coorg and British Burma all prisoners wore a coloured badge - blue, white, red or yellow - in order to facilitate easy recognition of the penal class to which they belonged. ${ }^{68}$

By the 1880 s, Indian jail officials were particularly concerned that habitual offenders (those twice or more convicted) should be treated differently. In some regions, such as in Madras, this included their being photographed and worked separately, in order to prevent them 'contaminating' other prisoners with their

65 IOR P/404/3 (6 August 1846). Petition of Shreerustna Wassoodewjee, 1 August 1846.

${ }^{66} \mathrm{Ibid}$. Minute of J.P. Willoughby, 2 August 1846.

${ }^{67}$ IOR P/146/30 (Judicial: Jails, August 1860). F.J. Mouat to R. Thompson, Junior Secretary to Government, Bengal, 9 August 1860.

68 IOR P/436/45. India Judicial Proceedings, 1869: Notes on Jail Administration in India, 9 January 1869. 
supposed criminal propensities. Increasingly, they were also made to wear distinguishing clothing. In Bombay, from the 1880s, habitual offenders wore a different uniform from other prisoners. In the Panjab, after 1885, all persons who were suspected of having given a false name or refused to reveal their identity - and thus suspected of being habituals - were made to wear special jackets and hats. The jackets had two dark blue stripes, three inches wide, running down each side. The caps had one central blue stripe, also three inches wide, woven into the fabric of the clothes. ${ }^{69}$ Later, in Madras Presidency, a new 'penal stage' was designed as a harsh three-month introduction to prison life. As well as sleeping alone and working at hard labour (such as the treadmill), inmates would wear clothing made from rough, uncomfortable gunny cloth. Habitual thieves would be made to wear a blue cap. ${ }^{70}$

The Andaman Islands were established as a penal settlement after the 1857 Uprising and eventually replaced Southeast Asia as the destination for all Indian transportation convicts. Initiatives on convict dress there were contemporaneous to those on mainland India. At the time of settlement, the Islands were inhabited exclusively by aboriginals. As in earlier Southeast Asian and Mauritian penal settlements, the need for a socially differentiating uniform was not, therefore, immediately apparent. During the early years, each convict was given one anna nine pice each year to clothe themselves. ${ }^{71}$

The latitude convicts were allowed with respect to clothing probably facilitated the replication of Indian social hierarchies. Convicts brought clothing with them from India, and wealthier convicts had better garments. ${ }^{72}$ Brahmins were allowed to wear the sacred threads. ${ }^{73}$ However, Robert Napier's report of 1864 noted the generally 'miserable appearance' of the convicts, remarking that 'most appear

\footnotetext{
${ }^{69}$ NAI Home (Judicial), A proceedings, December 1886, nos 117-219. Measures for the organization of reconvicted prisoners, 16 August 1886.

${ }^{70}$ NAI Home (Jails), A proceedings, February 1898, nos 32-4. G. Stokes, Chief Secretary to Government Madras, 27 June 1898.

${ }^{71}$ NAI Home (Port Blair), A proceedings, November 1871, nos 1-6.

72 NAI Home (Port Blair), A proceedings, June 1890, nos 74-8. Report on the Andamans by Mr C.J. Lyall and Surgeon-Major A.S. Lethbridge.

73 Portman, A History of Our Relations, pp. 303 \& 318.
} 
scarcely to have a rag to cover them. ${ }^{9} 4$ It was suspected that convicts were not spending their allowance on clothing: ${ }^{75}$ from this date all were subsequently supplied with actual clothing instead. This consisted of a short kurta and dhoti, stamped with the convict's number, initially made of thin American drill cloth and later with cloth manufactured in the Central Prison at Agra. ${ }^{76}$ By the turn of the century, the Andaman Islands had its own agro-industrial base, supplying many of the settlements' needs. Clothes were made by female convicts working in the Female Factory. ${ }^{77}$ Men got two kurtas and dhoti cloths per year; women two saris, giving a clean change of clothes twice a week. ${ }^{78}$ This surplus meant that it was possible for convicts working indoors, protected from the elements, to hoard or barter spare clothes. One Madras convict inspected in 1890, who had been in the settlement for less than two years, for instance, was found to have five suits of good clothing in his possession. ${ }^{79}$

It is perhaps no coincidence that the first attempts to clothe convicts in uniforms came as the settlement became more socially complex. By the 1870s, large numbers of convicts had been given tickets-of-leave on the condition that they settle on the island as self-supporters. As things stood, there was no way of differentiating between them and convicts under sentence of transportation, or between convicts in different penal classes. Superintendent D.M. Stewart made the first attempt to formulate a uniform in 1873 , trying unsuccessfully to dye the cloth received from India (with what colour we do not know) before it was issued to the convicts. Nevertheless, at the time of J.S. Campbell and H.W. Norman's report a year later, there was a crude form of hierarchy-by-garment, though no proper uniform. The

\footnotetext{
${ }^{74}$ NAI Home (Port Blair), A proceedings, 1 April 1864, no. 5.

${ }^{75}$ This sentiment was expressed, for example, in: NAI Home (Port Blair), A proceedings, November 1871, nos 1-6.

${ }^{76}$ NAI Home (Judicial), A proceedings, 12 August 1871, nos 18-19; October 1872, nos 247-50; and, November 1875, nos 1-3.

${ }^{77}$ NAI Home (Port Blair), A proceedings, June 1896, nos 1-2. The machinery in the Female Factory was capable of producing 24,000 suits of convict clothing each year.

78 NAI Home (Public), A proceedings, 7 January 1871, nos 107-8. H. Man's comments on an Extract from the Annual Medical Report, Port Blair, 1869.

${ }^{79}$ NAI Home (Port Blair), A proceedings, June 1890, nos 74-8. (Report of Lyall and Lethbridge).
} 
bottom three classes of convicts wore jail clothing; the top class their own clothes. ${ }^{80}$ Other indulgences followed this pattern. Convicts who reached the second class were allowed to cook their own food. Others refusing to eat in the common messing system which characterized the bottom classes were made subject to the harsh penal regime at Viper Island, a site of secondary punishment, where they could be coerced into doing so. ${ }^{81}$ Although during the first decade of the penal settlement, convicts and selfsupporters were not distinguishable from each other, things were beginning to change. By the early twentieth century, self-supporters and convicts dressed completely differently. Indeed, it was widely recognised that self-supporters would never don convict issue. ${ }^{82}$

As in Southeast Asia, convicts in the Andamans were integrated into the hierarchy of punishment. Thus convict jemadars (overseers) took their place in overseeing convicts. The organization of convicts in this way began on board transport ships, where warders were selected on the basis of 'intelligence' and good behaviour to oversee convicts. They wore a red cloth stripe around the right sleeve, just above the wrist. ${ }^{83}$ Once in the settlement, convict warders were easily distinguished from the penal labourers under their charge, clothed in red turbans, badges and coloured belts. As in Indian jails, they had to buy their own uniforms, out of their gratuity money. ${ }^{84}$

Another aspect to the organization of convicts in the islands was the use of European ticket-of-leave convicts as overseers. Imprisoned in India, these men were selected for transfer to the Andamans on the basis of their fitness, labour skills and ability to speak any of the Indian languages. Although technically not free men, as in

\footnotetext{
${ }^{80}$ NAI Home (Port Blair), A proceedings, August 1874, nos 51-84. Report on the Penal Settlement in the Andamans by Mr J.S. Campbell and Major-General H.W. Norman.

${ }^{81}$ NAI Home (Judicial), A proceedings, 30 December 1871, nos 9-10. In contrast, Hindu fever patients, quarantined on a hulk at Blenheim, were taken to shore daily to prepare their rations. NAI Home (Port Blair), A proceedings, March 1874, nos 50-1.

${ }^{82}$ NAI Home (Port Blair), A proceedings, August 1913, nos 32-5. During this murder trial, one of the key pieces of evidence was a bloodstained convict kurta. The accused, Sardar, claimed that he had been a self-supporter for too long to possess such a garment. On appeal, his conviction was set aside. ${ }^{83}$ NAI Home (Port Blair), A proceedings, March 1875, no. 43.

${ }^{84}$ NAI Home (Port Blair), A proceedings, June 1890, nos 74-8. (Report of Lyall and Lethbridge).
} 
the Straits Settlements European overseers were not expected to wear the same clothing as Indian convicts. Instead, they were clothed in what was effectively standard British working-class dress. On departure from India, each man was issued with four cotton or flannel shirts, trousers and socks (according to the season), two woollen coats, one straw hat and two pairs of strong shoes. The implications of this racialized issue of dress went beyond the aesthetic. In comparison, Indian convicts were issued with two suits of jail clothing and a blanket, ${ }^{85}$ the quality of which varied considerably from province to province. ${ }^{86}$ Inadequate clothing, particularly during the monsoon when a dry change of clothes was frequently unavailable, almost certainly contributed to sporadically high mortality rates in the settlement, in particular the incidence of dysentery. ${ }^{87}$

By the time of Lyall and Lethbridge's 1890 report, it was clear that convicts were to be explicitly classified through dress. ${ }^{88}$ Clothing had clearly become part of the disciplinary regime in the Islands - and a way in which convicts could counter it. Convicts were often caught wearing non-standard issue, and they were punished for doing so. ${ }^{89}$ Lyall and Lethbridge made several further recommendations relating to dress. Notably, habitual thieves should be visibly distinguishable from other convicts, on the grounds that they were more likely to reoffend than those convicted of serious crimes, like murder. Their distinctive clothing would be changed if they had no thefts recorded against them for a period of five years. ${ }^{90}$ In addition, by the end of the decade, particularly 'dangerous' offenders such as dacoits (gang robbers) wore a shirt and dhoti marked with red cotton thread. Thieves wore a small red badge on their chests. ${ }^{91}$

\footnotetext{
${ }^{85}$ NAI Home (Port Blair), A proceedings, March 1875, no. 43.

${ }^{86}$ NAI Home (Port Blair), A proceedings, June 1890, nos 74-8. (Report of Lyall and Lethbridge).

${ }^{87}$ NAI Home (Port Blair), A proceedings, May 1905, nos 9-13.

88 NAI Home (Port Blair), A proceedings, June 1890, nos 74-8. (Report of Lyall and Lethbridge).

${ }^{89}$ See, for example: NAI Home (Port Blair), A proceedings, November 1888, nos 90-4.

90 Ibid.

${ }^{91}$ Mrs Talbot Clifton, Pilgrims to the Isles of Penance; orchid gathering in the East (London, 1911), p. 77.
} 
Fears about sexual disorder also forced the development of distinctive convict dress. In the Andamans, where during the second half of the nineteenth century male convicts outnumbered female convicts by an average of ten to one, ${ }^{92}$ homosexual relations appeared to be common. Commentators firmly distinguished active sodomites from passive recipients (catamites) and juvenile convicts were seen as a particular target for older men. During the early decades, these 'lads' were locked up in lattice cages at night, within their barracks, in an attempt at segregation. ${ }^{93}$ This was by no means an ideal arrangement, particularly with regard to fire risks. As the settlement expanded in the 1880 s, all men and boys labelled 'habitual recipients' (catamites) were instead confined in and worked from altogether separate barracks. ${ }^{94}$ Public flogging was used to punish convicts caught in flagrento. ${ }^{95}$

In addition, from 1887, catamites were made to wear brown-coloured clothing to ensure they lived and worked under close supervision. The merits of this arrangement were fiercely debated at the time: W. Birch, Superintendent T. Cadell's assistant, argued:

\footnotetext{
There are in my opinion great disadvantages attendant upon marking out by a distinctive dress (and thus advertising) habitual recipients ... in a community such as this every individual would become thus personally known to all, in itself a great disadvantage as evil [sic] disposed persons would thus at once be informed whom to approach with solicitations. ${ }^{96}$
}

\footnotetext{
92 Satadru Sen, 'Rationing Sex: female convicts in the Andamans', South Asia, 30, 1 (1999), p. 29.

93 NAI Home (Port Blair), A proceedings, April 1875, nos 16-19.

94 This was noted, for instance, by Lyall and Lethbridge. 'Habitual recipients' were lodged in the Aberdeen Barracks, one of the larges in the islands, and worked at stone breaking in Phoenix Bay. NAI Home (Port Blair), A proceedings, June 1890, nos 74-8. (Report of Lyall and Lethbridge).

95 NAI Home (Port Blair), B proceedings, December 1880, no. 3.

${ }^{96}$ NAI Home (Port Blair), A proceedings, March 1888, nos 101-19.
} 
Though there was a certain logic to his argument, Birch was overruled. Arguably, the ensuing arrangement reproduced Indian social practices by sanctioning types of homosexual behaviour. That sodomites were not clothed differently effectively delineated what was considered masculine (active) or effeminate (passive) sexual behaviour. The act of being penetrated itself was what was seen as 'corrupting'.

A further development in convict uniforms in the Andaman Islands was the issue of 'neck tickets'. As in Indian jails, each convict was given a metal neck ticket on arrival in the settlement. Each was circular in shape, and detailed each individual's number, section of the Indian Penal Code under which convicted, date of sentence and date release was due. Such information was similar to that previously inscribed in convicts' forehead godna markings. If of 'doubtful' character, the ticket was also marked with a ' $\mathrm{D}$ '; if a member of a gang in India, with a star; and, if a life prisoner, with an ' $L$ '. There were some problems with the tickets. Iron was a valuable exchange commodity for the islands' indigenous inhabitants. In 1860, for instance, eight Andamanese raided a working party between Atalanta Point and Navy Bay, stealing tools and the convicts' tickets. ${ }^{97}$ Convicts may also have been open to barter. For this reason, from 1896 iron tickets were replaced with wooden ones. ${ }^{98}$ The tickets were worn during the first five years of a convict's transportation and could then be removed for good conduct. Petty officers did not wear neck tickets. ${ }^{99}$ If convicts committed a secondary offence after the removal of their tickets, they could be reissued with one bearing the letter ' $\mathrm{D}$ '. ${ }^{100}$ Convicts were regularly punished for refusing to wear their tickets. This was particularly pronounced when they were

\footnotetext{
97 Portman, A History of Our Relations, p. 303. Portman also notes a captured Andamanese had a convict's ticket in his possession. Ibid., p. 318.

98 NAI Home (Port Blair), B proceedings, February 1896, nos 64-6. Existing convicts retained iron tickets, which explains why contemporary observers and secondary commentators offer conflicting descriptions of neck tickets. R.C. Majumdar, Penal Settlement in Andamans (New Delhi, 1975), p. 131 and S.N. Aggarwal, The Heroes of Cellular Jail (Patiala, Panjab, 1995) claim that the tickets were wooden, in contrast to contemporaries Rosamund E. Park, Recollections and Red Letter Days (private circulation, 1916), p. 52 and Talbot Clifton, Pilgrims to the Isles of Penance, p. 91.

99 Talbot Clifton, Pilgrims to the Isles of Penance, p. 91.

100 NAI Home (Port Blair), A proceedings, August 1896, nos 39-45 and NAI Home (Port Blair), A proceedings, September 1896, nos 79-84..
} 
stationed in the neighbouring Nicobar Islands, away from the headquarters of the main settlement. ${ }^{101}$

The wearing of the tickets, and uniform convict dress more generally, later became a focus of outrage for the political, nationalist prisoners sent to the Andamans in the early twentieth century. A large 'S' was sewn on the clothing of those convicted of sedition; a ' $\mathrm{C}$ ' denoted those convicted in conspiracy cases. All nationalist prisoners also wore neck tickets inscribed with a 'D', for 'dangerous.' 102 This was quite unlike arrangements made for the reception of the Manipuri political prisoners, received in 1891, who had their own clothing sent from Assam. ${ }^{103}$ The Manipuris were transported to the Andamans after a revolt against the British. Most were members of the royal family, which perhaps explains the more accommodating attitude towards their dress. For twentieth-century political prisoners marked in this way, contact with each other, at work or mealtimes, became difficult. Their ordinary prison dress was also one way in which the nationalist prisoners were associated with the 'common criminals' with whom they were incarcerated. ${ }^{104}$ One such prisoner, Nanigopal, refused to wear prison clothing and broke his wooden neck ticket so many times that it had to be replaced with an iron one. ${ }^{105}$ Another, Barindra Kumar Ghose, wrote in his memoirs: 'I understood that here there was no such thing as gentleman [sic], nor such thing as man, here there were just convicts'. ${ }^{106}$

Related to the development of uniform convict dress was the close cutting, shaving and cropping of head and facial hair. In Indian mainland jails, haircutting was seen to have positive implications for hygiene, particularly the control of head lice. It

\footnotetext{
101 See, for example, NAI Home (Port Blair), A proceedings, August 1872, nos 1-2. Roll of summary punishments awarded to convicts stationed at Nancoury, June 1872. Seven convicts were fined two annas each.

102 Ujjwal Kumar Singh, Political Prisoners in India (New Delhi, 1998), p. 55.

103 NAI Home (Port Blair), B proceedings, June 1892, nos 76-80.

${ }^{104}$ Aggarwal, The Heroes of Cellular Jail, p. 195.

105 Singh, Political Prisoners, p. 57. See also V.D. Savarkar, The Story of My Transportation for Life (Bombay, 1950), pp. 238-42.

106 Barindra Kumar Ghose, The Tale of My Exile (Pondicherry, 1922), p. 53, cited in Singh, Political Prisoners, p. 56.
} 
was also bound up with the enforcement of prison discipline. In particular, the threat of headshaving was a means to control female prisoners in a social context where other forms of corporal punishment were not sanctioned. Hair cropping was also used on male and female convicts in the Indian penal settlements. It was not as common as in the Indian jails, but was used to punish refractory conduct after transportation. The presence or absence of head and facial hair was thus a visual tag through which aspects of prisoner and convict status could potentially be discerned.

In the Bengal Presidency, jail rules directed that all male prisoners have their hair and beard shaved off once sentence was passed. After 1856, to prevent the innocent being stigmatised as guilty - a shaved head invariably pointed to an individual's recent release from prison - this was altered to after the conclusion of an unsuccessful appeal. Prisoners were subsequently shaved every 15 days, by specially employed barber prisoners. In an attempt to avoid the threat of prison unrest, exceptions were made on the basis of those religious distinctions which the authorities thought were significant. Thus Muslims only had their hair and beard clipped with scissors. Sikhs, kols and Faraizis (Muslim reformists) did not have their hair or beards cut at all. The Inspector-General of Prisons, F.J. Mouat, required hair to be reasonably short, but only if there were no religious sanctions against it. Otherwise, prisoners were forbidden from growing 'the long greasy, dirty, elf-locks in which they so much delight.' 107

As for prison dress, the problem for jail officials was to ascertain whether prisoners objecting to hair or beard shaving did so on the basis of religion or caste, or other factors. There were invariably disagreements about prisoner objections. In 1857, for instance, prisoners in Mymensing went on hunger strike in protest at having their beards trimmed. The District Magistrate subsequently suspended the practice on the grounds that the men were Muslims. Mouat on the other hand saw this a moral victory

\footnotetext{
107 IOR P/145/51 (27 November 1856). F.J. Mouat to C.J. Buckland, Junior Secretary to Government Bengal, 13 November 1856 and IOR P/145/64 (25 June 1857). F.J. Mouat to C.E. Lance, Magistrate of Mymensingh, 8 May 1857.
} 
which would make the future enforcement of jail rules difficult. ${ }^{108}$ Whilst claiming to be sympathetic to prisoners, Mouat rarely conceded to their protests where they conflicted with points of discipline. Thus, by his own account, he refused to allow prisoners to cook their own food, wash their own clothes or sweepers to sub-divide themselves in order to carry out prison cleaning duties. Prisoners' protests on these matters were, he claimed, 'dignity objections', not in reality based on religious grounds. ${ }^{109}$ Other colonial officials were nervous of the effect that this veiled dismissal of caste might have on jail order. The Junior Secretary to Government urged Mouat to ensure that he was correct: 'Religious prejudices are not always to be set aside, merely because they are mistaken.' 110

During the 1860 s and 70 s, the Bengal rules on head shaving became more formally bound up with both Indian cultural practices and hierarchies within the jails, in particular the nature of the offence for which prisoners were convicted. Rule 193 of the 1867 Bengal Jail Code exempted any prisoners, such as Sikhs, to whom cutting hair would be 'offensive or degrading'; 111 after 1870, only habitual offenders and those sentenced to hard labour were close cropped upon their initial incarceration. ${ }^{112}$ In British Burma, where men commonly had long hair, it was decided that, as in Bengal, hair would only be cut on final confirmation of sentence. ${ }^{113}$ In what David Arnold describes as an 'elaborate lexicon of bodily signs and ritual practices', Bombay jail manuals made similar provisions. ${ }^{114}$ In 1886, the Amended Rules on the Subject of the Cropping or Shaving of Hair of Convicts in Jail ordered that no prisoner would have their hair cut during the month preceding release. Shaved hair stigmatised ex-cons, making it difficult for them to find work and likely they would

\footnotetext{
108 IOR P/145/64 (25 June 1857). C.E. Lance, Magistrate of Mymensing, to F.J. Mouat, 15 December 1857 and F.J. Mouat to C.J. Buckland, 8 January 1857.

109 Ibid. F.J. Mouat to C.J. Buckland, 11 February 1857.

110 Ibid. C.J. Buckland to F.J. Mouat, 31 January 1857.

111 IOR P/433/33. Memorandum of F.J. Mouat, 8 April 1870.

112 IOR P/433/33. Memorandum of F.J. Mouat, 8 April 1870.

113 NAI Home (Judicial), A proceedings, 16 September 1871, no. 15. C.B. Cooke, Assistant Secretary to the Chief Commissioner of Burma, to E.C. Bayley, 17 October 1871.

114 Arnold, 'The Colonial Prison', pp. 174-5.
} 
end up back in prison for some petty offence. At the same time, the 1886 Rules expressly bound hair cutting to the prisoner hierarchy. Neither prisoners sentenced to simple imprisonment nor convict warders were to have their hair cropped or shaved. ${ }^{115}$

Whilst awaiting transportation, convicts were subject to the same rules as ordinary prisoners, and so had their hair and beards cut. However, in the penal settlements, convicts were allowed to let their hair grow, and cropping was not common practice. Indeed, none of the prisoners represented in J.F.A. McNair's Singapore photographs have been close cropped, even the fifth class 'incorrigibles'. This is somewhat surprising, given that hair cropping was used as a secondary punishment. One visitor to Port Blair in the early 1900s, C. Boden Kloss, saw some of the inmates at Viper Island Jail, where recalcitrant convicts were sent, having their hair close cut. ${ }^{116}$ This practice was only abolished in 1915, on the suggestion of the Superintendent of Convicts at the time, Reginald Craddock. ${ }^{117}$

Joy Damousi, in a provocative account of gender and sexuality in colonial Australia, has explored the significance of headshaving female convicts there. First introduced by Governor Ralph Darling in 1826, for third class and 'incorrigible' women ('rebellious hussies') in the New South Wales Female Factory, Damousi argues that it assumed a particular significance within nineteenth-century constructions of femininity. Headshaving defeminized, disgraced and shamed women. ${ }^{118}$ Hair cropping was also used to discipline women incarcerated in India. Unlike male prisoners, women did not have their hair cut on entry into jail. Their hair was only ever cut or trimmed for two reasons: 'health and cleanliness' or 'flagrant or

\footnotetext{
115 NAI Home (Judicial), B proceedings, August 1886, nos 183-4.

116 C. Boden Kloss, Andamans and Nicobars (New Delhi, 1971 [first published 1902]), p. 20.

117 L.P. Mathur, Kala Pani; History of Andaman and Nicobar Islands With A Study of India's Freedom Struggle (New Delhi, 1985), p. 64.

118 Joy Damousi, “ "What punishment will be sufficient for these rebellious hussies?" Headshaving and Convict Women in the Female Factories, 1820s-1840s', in Ian Duffield and James Bradley (eds), Representing Convicts: New Perspectives on Convict Forced Labour Migration, (London, 1997), pp. 204-14.; Joy Damousi, Depraved and Disorderly: Female Convicts, Sexuality and Gender in Colonial Australia (Cambridge, 1997), chapter 4.
} 
continued misbehaviour'. ${ }^{119}$ In practice the former was rare, though haircutting appears to have been remarkably effective in punishing the latter. In Bombay, for example, whilst headshaving was used extremely infrequently, just twice between 1887-92 for instance, it seems to have had the desired effect - of providing a stick to beat the prospect of female prisoner resistance. The Inspector General of Bombay Prisons reported that it was a more effective disciplinary tool than solitary confinement or rationing, the only other options open to punish female prisoners, and lamented its potential withdrawal as a punishment. ${ }^{120}$

The assault on Indian womanhood which headshaving represented, and the outcry it could occasion, though little used in practice, led to its banning from Indian jails in 1892. This was much earlier than its withdrawal from Southeast Asia. Yet headshaving was still used as a secondary punishment. In the Andamans, women could also be punished by hair cropping. Campbell and Norman noted this in their 1874 report. ${ }^{121}$ Mrs Talbot Clifton, who visited the Islands in 1910, reported seeing a 'sullen-looking female' having her hair cut in the Female Factory there. Echoing her contemporaries in India she noted: 'the greatest punishment which can be inflicted upon a woman who is ill-behaved in jail is to cut the delinquent's hair'. ${ }^{122}$ Close cropping was not withdrawn from the Port Blair book of punishments until 1915.

The development of penal dress in the Indian penal settlements reflected changes in their structure and organisation. Integrally related to the abolition of godna tattooing in the mid-nineteenth century, clothing was used as a means to define and identify convicts as part of a total population of forced labourers. Clothing and hair cutting also became mechanisms through which convicts could be integrated into the hierarchy of punishment, and showed their movements up and down the penal ladder. Turbans, badges and belts were all used to mark out convicts employed as petty

\footnotetext{
119 NAI Home (Judicial), B proceedings, August 1886, nos 183-4.

${ }^{120}$ NAI Home (Jails), A proceedings, December 1893, nos 117-9.

121 NAI Home (Port Blair), A proceedings, August 1874, nos 51-84.

122 Talbot Clifton, Pilgrims to the Isles of Penance, pp. 127-8.
} 
officers. Symbols of their authority, these adornments were representative of wider socio-penal divisions between convicts: clothes marked types of offences, penal class and sexual identities.

Yet especially during the early years of the settlements, clothing and head/facial hair were spaces within which convicts could retain elements of their pretransportation identity. Convicts could wear clothing closely related to non-convict identities, whether these were forged in India (region of origin, religion or caste, for instance) or after shipment (perhaps independent economic activity and the accumulation of wealth.) Sometimes, the existence of these non-convict identities was sanctioned by the colonial authorities, either as a means to cut costs or foster social stability in the settlements. In other instances, convicts went directly against colonial directives on dress. Clothing was thus a medium through which convict identities were both made and unpicked. If the penal authorities used clothing in an attempt to fashion convict identities, so too convicts refashioned their own status through dress. 